\title{
Chapter One
}

\author{
HORIZON-CONVERSION-NARRATION \\ IDENTITY AND OTHERNESS IN THE SCIENTIFIC WORLD OF \\ THE HUMANISTS
}

by Andrzej Pawet Wejland

\section{Horizon}

Unexpectedly for some, but with full conviction that it will be of benefit to this manuscript, I reach at the beginning - to the deliberations of Bernard J.F. Lonergan and his work Method in Theology (2003). I have found there a good introduction to the topic of horizons that I am interested in. "In its literal sense the word horizon-writes Lonergan-denotes the bounding circle, the line at which earth and sky appear to meet. This line is the limit of one's field of vision. As one moves about, it recedes in front and closes in behind so that, for different standpoints, there are different horizons. Moreover, for each different standpoint and horizon, there are different divisions of the totality of visible objects. Beyond the horizon lie the objects that, at least for the moment, cannot be seen. Within the horizon lie the objects that can now be seen" (ibid., pp. 235-236). The literal meaning should, however, lead me-I am not mistaken in my premonition-to the metaphorical meaning. Therefore, I read in Lonergan further: "As our field of vision, so too the scope of our knowledge, and the range of our interests are bounded. As fields of vision vary with one's standpoint, so too the scope of one's knowledge and the range of one's interests vary with the period in which one lives, one's social background and milieu, one's education and personal development. So there has arisen a metaphorical or perhaps analogous meaning of the word, horizon. In this sense what lies beyond one's horizon is simply outside the 
range of one's knowledge and interests: one neither knows nor cares. But what lies within one's horizon is in some measure, great or small, an object of interest and of knowledge" (ibid., p. 236).

This approach makes it possible to state that horizon-let me clarify right away that I mean here conceptual, epistemic horizons, etc.-is what defines an image or a vision of the world within our knowledge. A determined (i.e. having its boundaries) horizon is, therefore, a way to comprehend the reality and conceptualize it, dependent on how our field of vision is determined by the place in which we are situated and from which we look-our point of view. This approach, in addition to the limitation of the horizon, assumes the possibility of changing it with the shift of locus standi-a point which is an embodiment of ourselves in the imagined, suggested by a metaphor, sphere of knowledge and cognitive interests. This 'shift' will be of particular interest for me in the further part of this work.

\section{Conversion as a Change of Horizon}

The metaphor of a point in which one is situated, from which one looks and observes the world in a horizon, is very flexible. If we crouch in this point, we will surely see the world from a different perspective: a photographer would call it a worm's-eye view, but undoubtedly it can also be a child's view or a junior research worker's view (thus we have a metaphor in a metaphor!). And if we jump or fly up, or stand on a comfortable, paradigmatic stool, will our view not change as well? Does the academic discourse community which can live very close to the ethnographic soil (deeply rooted in empirical research) not have a different view of the world (even a 'very anthropological discourse') than the one that feels the chill of the soil and goes to the sky of philosophizing (and methodological) abstractions (i.e. the one that loves working in an office at a desk and is not keen on fieldwork)? A point of view can be also altered by: 'up-down' movement, complemented by 'left-right,' 'forward-backward,' and even 'around'-everything depends on how our 'body' (of a single researcher or the whole community) in positioned in space. The words I am using here should be interpreted with all connotations appropriate for them in our culture, they ought to be taken in their full symbolic bloom.

What is more, there is a possibility of-and now it will become exciting-a shift that leads out from a given point, a shift of one or two steps, but also of scientific miles. When a shift concerns moving from one discourse community to another, in particular moving from one paradigm to a different one, from one horizon to another horizon, especially a radically different horizon, we speak about conversion. Bernard J.F. Lonergan rightly 
argues that conversion concerns not only replacing one horizon with another, but also a change within the horizon, although a conversion through 'replacement of horizons'-as usually more 'dramatic'-probably rivets our attention more strongly. Scientific conversion is a variant of intellectual conversion, and perhaps also of moral and religious conversions (ibid., p. 237 and subsequent ones). It should be considered, as Lonergan claims, a variant of self-transcendence, of elevation that requires breaking with "often long-ingrained habits of thought and speech" (ibid., p. 239). Conversion may involve non-destructive, non-expunging memory, therefore, departing from a paradigm does not have to (and probably even should not) mean a 'biographical suicide.' It is better to choose the memory of departing over the total memory amputation-thus remembering the reasons for emigration and its path to a 'new world,' i.e. new discourse community. Only from such a dynamic perspective, one can see how the contexts are developingthe contexts that were entangling our thoughts and our vision of the world, also through the used language-and how we have enriched ourselves and our horizon.

Lonergan persistently emphasizes that conversion is something more than simply a change of horizon: conversion is also (I am using Lonergan's term here) a change of belonging: a change from one group to another or a change within belonging to the old group i.e. "one begins to belong to it in a new way" (ibid., p. 269). In the former case, it is possible to meet other 'converted' individuals, for example, converted from structuralism to phenomenological anthropology. Thus, what is also possible in a community discourse is the exchange of 'witnesses of conversion'-voices that confirm a new membership and critically dissociate themselves (but not without memory) from the old scientific environment. The emerging associations with a religious conversion are quite justified. In The Structure of Scientific Revolutions, quite a methodological work, Thomas S. Kuhn (2012) wrote about paradigms placed in specific research communities and did not avoid this self-suggesting analogy. For Kuhn, those communities bear (sometimes quite distinctively) features of religious cults, therefore, switching from a paradigm 'worshiped' by one community to another which is 'worshiped' by members of another community is tantamount to a conversion, sometimes very radical and violent. It is also a conversion to another 'scientific faith,' abandoning the old community, and even-from the perspective of the abandoned community-unforgivable betrayal. Shifting to another paradigm, which Kuhn called a "conversion experience" (ibid., p. 150), means not only a 'leap of faith,' but also a life-changing turnabout. Indeed, the 'leap of faith' has to have, as emphasized by Imre Lakatos, a mystical nature, and the scientific transformation resembles the religious one also because it means 
'following someone'-a new leader and his supporters (cf. Barbour, 1974). For Kuhn, "transfer of allegiance from paradigm to paradigm" was a decision based only "on faith" (Trigg, 1973, p. 104).

Presenting this matter in such a way, I assume the change of conceptual, i.e. epistemic horizons and consequent 'permanent' scientific emigration, whereas a contemporary transdisciplinary, postmodern discourse emphasizes a nomad idea: traveling from one paradigm to another, from one community to another. Maybe even wandering that does not end and is-in opposition to scientific settlement and putting down roots-a permanent condition, a new lifestyle. Who is a nomad-scientist? Such person may also have-besides 'portable scientific identity'-'portable homeland,' the thing is that such person is not devoted to any community or its research paradigm with which he/she is temporary connected (if the word 'connected' is suitable in this context at all), he/she does not have the feeling of joining or entering in the full confidence the 'inside' of the community. Migration from paradigm to paradigm, if we want to use here the word 'conversion' as well, is a migration in which a researcher can have a conceptual view of conversion at his/her disposal: he/she knows what conversion is, he/she understands the essence of it, and adapts himself/herself but without real commitment, therefore, he/she usually functions in the 'as if' mode, until he/she shifts to the next paradigm and a group of its supporters. Does he/ she have, in the traveling suitcase, something that he/she really identifies with, or-permanently deprived of deeper relations-he/she shall live in a peculiar state of weightlessness?

\section{Community of Discourse and Identity}

This problem could be easily resolved with the help of the concept of multiple identities, i.e. as many identities as many groups of (also scientific) participation. It is a very convenient concept releasing us from struggling with tensions and paradoxes of the identity-I mean identity understood as some unity. I choose the second option, not because I want to show how bravely I face difficulties, but because this option ensures the ability to reveal peculiar identity cracks, even in well functioning (as it would seem) humanists. Therefore, I am not interested in chameleons changing their skin color; I take into consideration more typical cases of being faithful, for a long time, perhaps even for a lifetime, to one 'scientific color.'

Can a person who is faithful (like a neophyte after conversion) to one scientific paradigm still experience some tensions - 'inside' and in relations with other members of a scientific community? Let us first consider whether he/she 'writes' one story with his/ her life. Kevin D. Murray (1995), following 
the suggestions of Mikhail M. Bakhtin and his concept of literary chronotopes, and other scholars referring to Bakhtin, drew attention to frequent splitting of an identity into different stories. These are 'true-life' situations: we tell (or our life 'tells') something here, and we tell (and our life 'tells') something else there. These situations are also known in science and, like other situations concerning 'split identity,' were given by Murray an umbrella term of "narrative partitioning." For example, one part of the split ' $\mathrm{I}$ ', involved in an anthropological discourse, and so a public discourse, will advocate analytical psychology of Carl Gustav Jung with great (as it seems) confidence; while the second part that manifests itself, let say, in a private, banquet discourse (even among colleagues-anthropologists) can deny this approach larger scientific value; it can also be the 'I' that, 'as an anthropologist' sticks to the enlightened clear-headedness and shuns all, as it calls them, superstitions, while as an 'ordinary man' avoids black cats crossing the path, going under a ladder etc. It is easy to notice that some discourses overlap and compete against one another in such ' $\mathrm{I}$ ', and therefore, the narratives presented in different social situations can be regarded as incompatible.

The tension is born here out of conflict of some social norms functioning in the scientific world. Some social norms certainly guard narrative cohesion: they make the expectation that a person who, as an ethnographer and anthropologist or another humanist, sees everything-this is just an example-through the prism of sun cults, will wear these glasses also during privately celebrated Easter, or the other way round-that a person who wants to spend not only Easter but his/her whole live, including his/her 'busy everyday life' as a Christian, will remain a Christian as a researcher-scholar. Other norms, demanding separation of these zones, express the expectation that the creation of a narration devoted to one of these spheres will be accompanied by 'silence' on the part of the narration from the second sphere. It refers especially to refraining from putting 'private' matters of denomination and religious faith into the public discourse. In such case, the 'silence' of private sphere narration, demanded by norms, consists in putting this narration in brackets, 'freezing' it, or even performing its total-in the scientific life-'annihilation,' and therefore, one way or another, preventing it from accessing the public sphere. The researcher 'as a scholar' should not ask himself/herself certain questions at all; as a scholar he/she should not seek answers to those questions, and, above all, as a scholar, he/she should not talk about 'those matters' among the research community. For a researcher 'as a scholar' is not-or should not be-a 'layman.' Meanwhile, however, 'lay people' ("in contrast to scholars qua scholars")-as Anna Wierzbicka writes in What Did Jesus Mean?, a few moments before an important personal confession (Wierzbicka, 2001, p. 16) -will always ask themselves some vital, 
existential questions, for example "the question of the relevance of Jesus' teaching to their own lives" (ibid.). A personal confession, which Wierzbicka drives at in the Introduction to explaining in "simple and universal human concepts" Jesus' sayings, is an act, which exceedingly assures of her striving to obtain narrative coherence in her book (and probably not just there): "[...] Finally, should the reader be interested in where I personally stand, I am a believing and 'practicing' Roman Catholic. At the same time, my perspective on the Gospels has been strongly influenced by the writings of Jewish, as well as Christian, scholars [...]" (ibid., p. 23). A reader, especially a skeptical one, who does not completely believe that it is only about a scientific semantic research, may after all want to know why she took on explaining Gospel parables (instead of leaving this task to Biblical hermeneutists) and choose as her main objective even "to launch a new type of exegesis, which can be called semantic exegesis" (ibid., p. 6).

As a narrativist who is convinced but still looking for methodologically interesting perspectives, I am inspired by the thought that the division into a public and a private sphere in a scientific discourse (although the boundaries of such a division can be shifted depending on the situation) often manifests itself not so much in the 'silence' of private narrations in public circumstances, but-if, for example, issues of private religiousness are brought up in such circumstances-in using their simplified, shortened, often even trivialized versions. Meeting other researchers and the reading academic audience, under the pressure of scientific norms, can consist in their transformation into perfunctory and reticent 'summaries,' told with a language that does not suggest religious commitment too openly and into forms from which confessional elements are almost or completely leached out. Those narratives can also be replaced-by changing the rhetorical mode or genre-by humorous or self-mocking narrations defensively distancing themselves from 'serious' inclusion of private matters into public discourse. Those situationally non-developed stories should not be mistaken for narratively 'immature' stories, which are not yet arranged and remain in a prenarrative or an antenarrative phase (cf. Wejland, 2010, pp. 172-173)-regardless of whether we can process them into 'well-formed' stories or only into 'less nicely built' narratives, as inter alia the so-called chaos narratives (Frank, 1995, pp. 97-114; Uehara, Farris, Morelli, \& Ishisaka, 2001).

What is important here is rather the way of 'editing' them-different in various social circumstances. When a person of deep faith, or a fresh convert uses such laconic, partly evasive and in a way substitutive forms of 'edition' in a public discourse, it means (I am referring exclusively to Christians) that such person does not yield to the encouragement of dauntless witnessing of God and one's religion. Anna Wierzbicka however, yielded to this dictate 
(I do not go deeper into her other reasons (if such existed)-like the will to satisfy the curiosity of the readers, as she writes), therefore, parrhesia is a term that can be used to refer to her direct honesty (cf. Wejland, 2003). The attitude described with that term was adopted even more clearly-because it happened in an elaborated story-by Margaret M. Poloma, however, as we will see, the story was transferred to the research community welcoming such narrations.

\section{Identity and Narration: Problem of Alienation in Science}

In this way, I am driving at a problem, which does not concern only the issue of-conventionally speaking-bringing together science and religious faith, because a narrative partitioning may appear on the verge of science and any other sphere of existence (especially if the sphere is important for the ' $\mathrm{I}^{\prime}$ ). However, this field is convenient for my deliberations, because it is expressive and full of perfect real-life examples.

What has been and still is the expectation of 'science,' including the whole area of humanities, and (so to say) modern anthropology as well, i.e. a science subjected to the Enlightenment ideals? The expectation is to separate the private sphere from the public one, and avoid anything 'confessional' in stricte scientific deliberations. Since this expectation is generally directed against the 'professed ideology' (or anything that 'functions as a religion'), fulfilling it should not mean the agreement to including the 'professed atheism,' manifestations of irreligious attitude, or any other worldview into the research community discourse. This consequence should perhaps go even further: it should be expected that no scientific, and therefore also no anthropological or sociological, theory of religion will be based on anything ideological or religious 'inside,' and so it will not employ any scientific doctrine transformed in something like 'faith,' for example the Mircea Eliade's phenomenology of religion-translated into a kind of confession.

It is worth to remember about the criticism that has been directed at his phenomenology of religion. One of the reasons for the criticism is that this phenomenology speaks of archaic and cosmic religion and of cosmic homo religiosus; it equates sacrum with what is primitive, and being very closely connected to Jung's philosophy and holistic philosophy, for some people, it seems to become a close neighbor of New Age. Andrzej Bronk (2003, p. 291), speaking about Eliade with warm feelings, writes, "Eliade is personally involved on the side of sacrum, religion, and man, and his books have something deeply religious. He reiterates that a proper understanding of the world and man's ultimate goals is possible only from the perspective of sacrum. Eliade's religiosity is a religiosity resembling more a Taoist sage 
than a Christian saint. His interest in cosmic religion (earth, air, fire and water as hierophanies) reminds Ionic philosophers of Nature. The cosmic religion has no place for a transcendent and personal God and personal contact with Him. [...] Eliade's ambition, however, was not to create a new form of religion, or a syncretic religion à la Eliade. He wanted to talk about religion and religious phenomena somehow beyond all theologies and dogmas. [...] Eliade sees on the one hand the uniqueness of Christianity and the fact of the Incarnation of God in the history of the world, but on the other hand he repeals it, treating Christianity as an extension of the archaic religion and identifying eschatological preaching of Christ with the archaic and Indian symbolism of the rebirth of the world. Moreover, from the position of cosmic religion, Eliade is critical towards the Judeo-Christian tradition, since it-allowing the creation of particular sciences-has contributed to [...], desacralization of the world criticized by him. However, he expresses the belief that the West and Christianity will get renewed through the recovery of the cosmic and sacred dimension of reality, crossing local restrictions by means of contact with Eastern religions. Eliade considers his works as contributory to achieving this task" (italics in the original).

Narrative tensions become visible after taking into consideration the fact that Eliade was brought up in the spirit of the Romanian Orthodox Church, but the journey to India, after obtaining his MA degree, immersed him into the teachings of Sanskrit and Yoga Philosophy thanks to the stay in the community of yogis in the Himalayan ashram (ibid., p. 268). When he died in Chicago, he "was provided with holy sacraments, in the presence of his praying wife and friends. The Orthodox churches in the United States celebrated the funeral prayer for his soul. The one-as Bronk writes-who used to say that the secular world is an illusion and death is a kind of initiation, went to the sacred dimension of reality, in whose existence he had always strongly believed" (ibid., p. 292).

Eliade must have felt his otherness in science, or at least in some of its areas. Here is one more passage from a thorough, extremely interesting text of Andrzej Bronk: "There are ethnologists and religious researchers who believe that what Eliade says is simply 'bad historiography, bad ethnography, bad method, bad psychology and also confusion of all concepts' (Edmund R. Leach). They deliberately ignore his work, or reject it critically as unscientific input. Other critics say that Eliade's statements are banal-who has read two of his books, has read them all" (ibid., p. 289). However, I have found a confession that weakens the above criticism in Louis Dupré's (2003, p. 13) (who writes 'as a Christian') work. This confession-at the subsoil of unreserved respect for Eliade and opposing Hegel's theory of religious negativity-builds a story of personal scien- 
tific conversion: "[...] my conversion to the dialectical view on religion has taken place entirely under the influence of positive and phenomenological research, especially the work of Mircea Eliade, and not under the influence of Hegel" (ibid., p. 14), admits Dupré.

One of more contemporary approaches to the problem of division or non-division of the ' $\mathrm{I}$ ' and the narrative coherence or narrative fragmentation can be found in the work of researchers who insist on revealing the ' $\mathrm{I}$ ' in anthropological narrations. Indeed, it does not always concern religion and religiousness, sometimes however, it certainly does. It is easy, while even flipping through the works of contemporary humanists, who like to refer to themselves as 'qualitative researchers,' to find stories in which they 'expose their inner self' using very personal rhetoric. For example, they treat the experience (tinged religiously) of a severe illness that struck them or someone close to them as the most appropriate subject of the socalled autoethnography. In this context, it is worth mentioning that some researchers consider 'moving out' from the world that is indifferent or hostile to personal religious commitment as the best option. They shift to the world that is friendly towards such commitment. With that goal in mind, they decide to-after intellectual conversion, but often also following religious conversion-take the path of changing the discourse community. As strangers in one community, they look for a different one in which they will be able to work without a personal split living also privately in the same non-divided horizon. A good example is Margaret M. Poloma-a sociologist and anthropologist, once a researcher of well-known 'secular' universities, after conversion to Pentecostalism (i.e. joining the Toronto Blessing movement) she became a member of the Association of Christians Teaching Sociology and a lecturer at the 'religious' University of Akron.

Let us first listen to what she says about the special relationship between religion and sociology in her life before the conversion (Poloma, 2001): “To paraphrase Emile Durkheim, the faith of my childhood was dying or already dead and a satisfying new faith was yet to be born. Neither Auguste Comte nor any of the masters of sociological thought could convince me that sociology could become the religion of my adult life. Although I devoured the prophetic writings of critical sociologists like C. Wright Mills and Alvin Gouldner, I was unwilling to make critical sociology (or any other sociology) my new religion. Instead I put religious concerns aside after successfully completing my doctoral prelims in the sociology of religion and adopted the stance of an atheistic existentialist and a sociological critic."

Following the conversion, those relations changed-faith did not reject sociology but required sociology to cling to religion: "Sociology was a game of life I intended to play, but I had no illusion that it would ever be 
worth the price of my soul. [...] I was to continue my search for integrating my faith and sociology" (ibid.).

Is it easy to practice sociology in this way, especially when it is sociology of religion? Is it still sociology of religion, or already-and still, as Danièle Hervieu-Léger (2000, pp. 9-22) would probably say-religious sociology? After all, Poloma openly claims that she wants to dabble in Christian sociology. She is aware that it is an unwelcome anomaly in the world of academic sociology: "Doing Christian sociology is much like riding a unicycle. There are many who feel that the godless discipline of sociology has nothing to say to Christians, while there are sociologists who insist that one cannot be an openly committed Christian and do good research" (Poloma, 2002a). Let us focus on (I realize that, unfortunately, it will be easy only for sociologists with deep insight into the field or transdisciplinary-oriented researchers of related disciplines), the way in which Poloma understands sociology (with no 'Christian' attribute): “Sociology represents a particular perspective or way of viewing the world. It includes a focus on how our societies and cultures are socially constructed by the people who live in them and how, in turn, these social constructs of laws, customs, and institutions 'act back' on their creators to shape and define who they are. Sociology, thus, assumes that the social world (including our religious beliefs and institutions) is created by people whose thought and behavior is shaped by that which came before them; they then modify the social world which will shape those who come after them" (ibid.).

The lack of space for extensive explanations forces me to mention only two things to illustrate the complications in sociological narratives that Poloma's casus may refer to.

The first issue is the presence of the name 'Holly Spirit' with different denotations and-of course-connotations, in the language of these narrations. I am convinced that Poloma refers this name to some real being (although transcendental for human reality), i.e. the third Person of the Trinity. Dealing with the witnesses of Toronto Blessing movement members (Poloma 1997; 2002b), she could have probably considered that she was interested only in the 'truth' of their narrations, and not the 'truth' understood in a kind of ontologically obliging way, which would have simply meant 'silencing' her of own commitment-but without its cancellation. Studying the acts of sharing the testimonies and other 'charismatic phenomena' and inquiring-after Victor W. Turner-how they create a community or how they are in favor of creating a symbolic community, she might have agreed to 'pass over in silence' the thesis that the community is ultimately created by the Holy Spirit. However, she would have firmly protested if someone had reduced the Holy Spirit to the collective 
consciousness, i.e. if someone had found the name 'Holy Spirit' originally empty and, wanting to re-assign (through explication) to it the referring unction, pointed to conscience collective as its 'real' designatum. That was the case of Matthew P. Lawson (inspired by Durkheim), in his well-known (probably also to Poloma) article entitled The Holy Spirit as Conscience Collective (Lawson, 1999). We easily notice how very different are the conceptual (epistemic) horizons of those two researchers-sociologists of religion. And how different are-rooted in language-the images of the world that are assumed by them and the discourse communities they are addressing their texts to, seeking mutual understanding.

The second issue is using the word 'miracle.' Margaret M. Poloma privately believes in extraordinary and miraculous actions of God in the world, and especially in his gifts-charismas. With what commitment level does she use the word 'miracle' in her texts, in which language does she read it and interpret the witnesses of other members of the Toronto Blessing movement? I will not answer these questions directly. Lonergan (2003, p. 222), in his deliberations concerning horizons in historic research and methodological theses of a historian Carl Becker, placed the following remark: "Can miracles happen? If the historian has constructed his world on the view that miracles are impossible, what is he going to do about witnesses testifying to miracles as matters of fact? Obviously, either he has to go back and reconstruct his world on new lines, or else has to find these witnesses either incompetent or dishonest or self-deceived. Becker was quite right in saying that the latter is the easier course. He was quite right in saying that the number of witnesses is not the issue. The real point is that the witnesses, whether few or many, can exist in that historian's world only if they are pronounced incompetent or dishonest or at least self-deceived. [...] Hume's argument did not really prove that no miracles had ever occurred. Its real thrust was that the historian cannot deal intelligently with the past when the past is permitted to be unintelligible to him. Miracles are excluded because they are contrary to the laws of nature that in his generation are regarded as established; but if scientists come to find a place for them in experience, there will be historians to restore them to history."

A little bit further on Lonergan writes that "possibility and the occurrence of miracles are topics, not for the methodologist, but for the theologian" (ibid., p. 226). Although a theologian himself, he-as a methodologist-adapts the clause of 'silence' here imposing un-touching, excluding those issues from the range of deliberations, from 'speaking.' 


\section{Dialectics of Horizons-Towards Hermeneutics}

I want to use the word 'dialectics' in one of its most primal meanings, which refers to putting together notions and assumptions in a rational way, revealing the tensions or unanimity between ideas, concepts and other views. When I speak about the 'dialectics of horizons,' I mean the 'conversation' between them, which is dependent on such a combination that contains an attempt to understand one horizon within or on the basis of the other. For Bernard J.F. Lonergan, however, the dialectics of horizons means first and foremost dealing with all their conflicts-the issues that separate them and that cannot be removed by a discovery of new facts or aspects of the examined phenomena, because those issues have a rather fundamental nature: they derive from-different for each of them-explicit or implicit vision of the world, from the adopted theory of cognition, and also from the specified religious or ethical worldview, etc. (ibid., p. 236). In Lonergan's work, we immediately find a hint that this fundamental conflict exists between the two horizons in a biography (for instance a scientific biography) which is split by a conversion: namely, between the horizon which was adopted before conversion (let us name it H1) and the horizon adopted after conversion (H2). As we remember, only in particular cases conversion has a religious basis or is simply a religious conversion. In general, for Lonergan, for me, and for many other researchers, conversion means every, especially radical, change of horizon. For example, in A Dictionary of Sociology under the entry Conversionism, the author who did not provide his/her name writes, "The term can also be used in a more general sense to mean the acquisition of a new role or ideology. This general sense would embrace, for example, the idea of conversion to socialism" (w.a., 2009, p. 132).

What is now important for me is the observation that the dialectics of $\mathrm{H} 1$ and $\mathrm{H} 2$ makes the converted person go back to $\mathrm{H} 1$ (with which he/she is not connected by commitment anymore) from the position of $\mathrm{H} 2$ (which he/she is committed to due to conversion)-go back, that is include it in a biographical reflection, analyze it from the newly obtained perspective of a new paradigm. Paul Ricoeur (1988, p. 246) would call it a 'reading of oneself' - that takes into account the time and the autobiographical narration shaped according to it. During this 'reading,' i.e. interpreting, we think about "oneself as another"-the same and different at the same time, wrapped in the lines of telling one's own life, 'halved' by conversion. This 'reading' is a hermeneutic procedure: $\mathrm{H} 1$ and $\mathrm{H} 2$ belong to one person, but it is not-because of conversion-'the same' person (cf. Wolicka, 2003). 
The prototype of this hermeneutic situation is, of course, 'reading of others.' $\mathrm{H} 1$ and $\mathrm{H} 2$ are properties of different people: an author of a text and its interpreter. The interpreter 'reads' the text of the author, contributing his/her own horizon to this process and trying to 'meet' the author's horizon in order to understand the text; because the condition of understanding is always pre-understanding (determined by our biographical, temporal horizon)-all that we have approaching the text we want to understand and all that we bring into the understanding of it. One cannot exclude his/her own horizon from understanding someone else and his/her text, therefore, pre-understanding cannot be excluded or 'skipped.'

In which hermeneutical situations is it easier and in which is it harder to reach such 'meeting' of horizons? I leave this question unanswered at this general level, albeit I will attempt to make some specific comments.

The proximity or distance of horizons (understood ahistorically) is the first of two issues that are perhaps the most important to me now, and I see it on a specific example. How the text is 'read' and interpreted, and how it can finally be understood and is understood by a hermeneutist, whose horizon is in tension with the horizon of the text since, for example, the text is religious in nature and the hermeneutist based his/her horizon of understanding on totally secular visions of the world and man? How, in turn, is the same text 'read' and interpreted by a hermeneutist who is a homo religiosus himself/herself-either from 'the beginning' or as a result of religious conversion?

There is a well-known thesis that only a homo religiosus can really understand experiences reported by another homo religiosus, i.e. the text of his/her 'spiritual autobiography,' especially if they both believe in the same thing and in the same way (to put it simply: they are followers of the same religion). For example, Simon Blackburn (2005, p. 84) elaborates this thesis in the following way: "Christian doctrine can only become evident after belief in it. The idea, especially frustrating to atheists, has echoes in the doctrine associated with the later work of *Wittgenstein, according to which immersion in a way of life is necessary for understanding its specific structures and guiding concepts."

A similar thesis is the statement that only someone experienced conversion (intellectual, moral or religious) can understand what other convert says or writes, even if it is a person 'converted to socialism,' or to hermeneutics, psychoanalysis, or symbolic anthropology in one of its variants. The supporters of this thesis insist that the experience of selftranscendence, which appears during conversion (and also encompassing oneself as another) is basically unique and non-transferable. 
A certain practical aspect of this issue is also important: treating interpretations of the utterances collected by the researcher in the field as a kind of translation. Deliberating on this issue, I like to refer to (therefore, this is not the first time I have done it) Przemysław Owczarek's (2006) research in the Podhale devoted to the social and cultural image of John Paul II during the Pope's life. In this research, Owczarek did not exaggerate in his focus on the notion of image, instead, he acknowledged that the two "pillars' of this notion are "life" and "presence." He puts these two words in inverted commas on purpose, because he means mythical life although set upon historical background, and also mythical presence similarly connected to history. The concept also contains-among other ideas-the idea of the cult of John Paul II specified according to the anthropological understanding of ritual and religion, with embedded intuitive presumption (destined for empirical, field testing) that this cult goes beyond the catholic orthopraxis, and even contradicts it: doctrinally erroneous and incorrect, mixed with quasi-cult behaviors typical for contemporary idiolatry, in the melting pot of 'folk piety.' Thanks to the field research, Owczarek was able to fill this whole concept with rich and vivid content, which eventually led to confirming the initial hypotheses, although they demand further specifications and development. His concept clearly engaged a specific theoretical and paradigmatic perspective, for example, he used the symbolic anthropology of Victor W. Turner to analyze the phenomena of ritual and cult placing (following Geertz's style) a dense description of a procession in the Sanctuary of Our Lady of Fatima in Krzeptówki into the frames of symbolic anthropology. As we can see, Owczarek himself did not have the ambition to create his own theory-he skillfully adapted theories of other researchers (not only Turner). How, did he, however, as an anthropologist seriously equipped with language and scientific notions and brave enough to confront a cult spreading among people living in Podhale with his own perception of this cult's doctrinal correctness, translate their utterance into this language and notions?

Generally speaking, translation is "an operation involving formulating in a language an equivalent to the utterance previously formulated in another language" (Kostkiewiczowa, 2000, p. 446). "Is it about-I asked this question before-just 'keeping the meaning'? If an interpretation is a translation, it is a special translation: in a language external to the statement it tries to reveal, but also to explain the meaning contained in it-the startingpoint of interpretation is the assumption that this meaning is hidden and cannot be derived directly, but requires relevant rules of 'reading.' The result of interpretation should therefore be a text displaying the meaning 'read out' of a given utterance. Interpreting translation-let us stick to this 
term-not only 'shifts' a statement into a different language (which is suggested by the Latin word translatio), but also 'explicates' that statement in the other language (which is why we also call this procedure explication). Interpreting translation is not, as you can see, an ordinary translation: it is not about 'keeping the meaning,' but 'transcoding' an utterance into a language which-reaching into its deep levels of meaning-at the same time will explain in its own way (i.e. light up, make closer) something of what was revealed on the surface. In its own way-i.e. in the horizon proper for it, giving a new context to the sense read out from the depth, such as a context of anthropological, historiographical, sociological, and literary ideas, concepts and theories, etc." (Wejland, 2010, p. 179).

The above case, as well as other cases of interpreting translation, is related to the problem of translatability. Translatability is generally defined as "susceptibility of a text contained in a certain language to having an adequate equivalent formulated in other languages" fortunately with the added remark that "absolute translatability is only a theoretical ideal, which in the reality is replaced by different degrees of approximations only" (Kostkiewiczowa, 2000, pp. 447-448). It also concerns all interpreting translations-of religious or any other texts-conducted by a humanist researcher, including an ethnographer-anthropologist. Without excessive methodological maximalism, we can therefore ask here: whether, and to what extent such translation considers or skips, preserves or loses in the 'target' text (in our case-the anthropological interpretation) the whole deep layer of metaphors, images and symbols contained in the 'source' text (in our case-the utterances provided by informants). Is it not so that some source texts, for example texts of religious character, cannot be, as a matter of fact, translated into the language of anthropology 'without some loss'? Does anthropology not make any reductions in its 'interpretation of the interpretation'-wasting the metaphors, images and symbols of the source texts?

Perhaps, however, this problem should be put differently: is it not so that translatability is guaranteed only when interpreting translation is made by anthropologists who are 'religious people' themselves? Such formulation may be confirmed by the thesis that the language of metaphors, images and symbols-and religious language is reportedly 'by nature' such language (with the language of mysticism certainly being such language)-can only be understood through committed reading, i.e. by personal religious experience. What, however, should anthropologists who have different attitudes do? Would they be entirely or partially deprived of the successful hermeneutic access to the texts of religious character, because of their 'deafness and blindness' to deep religious meanings? This problem obviously embraces all similar cases of incongruence i.e. lack of harmony between 
a horizon and a language of a researcher-interpreter and a horizon and a language of an informant-author of a certain source text.

Another issue that I want to mention here is connected with taking into account, by the interpreter, the interpretation given by the authorits acceptance and 'absorption' or disacceptance and 'rejection.' In both cases, we are dealing with-as Thomas J. Csordas (1994, p. xi) says-“an interpretation of an interpretation," and we use "double hermeneutic" i.e. "a hermeneutic of a hermeneutic": we put our own understanding on the author's understanding, we, in a way, 'let the author's horizon into our own horizon' - we expand our horizon by his/her interpretation, analyze it impartially from our point of view, or negate it-with less or more commitment. This is unvaryingly underpinned by the community that shares our horizon of understanding: the view of the world retained in the language and hermeneutic consciousness of this community.

An interpretation of an interpretation can be, for example, as in Csordas' (1994) or my works (Wejland, 2004), an anthropological (i.e. developed in the anthropological community of discourse) interpretation of religious interpretations included in the testimonies of faith of the Charismatic Renewal members; and a hermeneutic of a hermeneutic can be-accordingly-anthropological hermeneutics (and not, for example, theological hermeneutics) of religious hermeneutics revealed in the testimonies (theological hermeneutics of testimonies is developed by Paul Ricoeur in one of his works (cf. Ricoeur, 1980; see also, Dziewulski, 2002)). It does not exclude more complex situations involving infusions and mergers of different interpretations and types of hermeneutics-anthropological hermeneutics with theological hermeneutics or the other way round. The language of theology often forces its way into anthropological interpretation, and theological interpretations are full of anthropological words, small ideas and quite serious concepts or theories.

This issue, of course, concerns not only Csordas and me, and not only anthropology. Many words from religious and theologians' language invade the sociological narration presented by Margaret M. Poloma. Her hermeneutics (just as Csordas' and mine), however, attempts to remain a hermeneutics that overbuilds itself over the "native exegesis" (Victor W. Turner's expression), moreover-it accepts 'native' reports or testimonies of charismatic experiences with trust or at least without questioning their veracity. In this way, she explains what it means that her research report uses a sociological approach relying on such acceptance: "This report uses a sociological approach with its strengths and its limitations to assess the effects of the so-called 'Toronto Blessing.' It is outside the sphere of the sociological perspective to call upon either God or the demons to explain 
what is happening in the renewal. Nor can sociology as a scientific discipline proclaim judgment about whether a given outcome is 'good' or 'bad.' (Often what is 'good' for one group of people may be 'bad' for another.) It strives for objectivity, and the information it gathers must be empirical (i.e., capable of being measured using the tools of social science). It is subjective only in that sociology relies on people to tell their stories through narrative or filling out questionnaires, accounts that are based on personal judgments. As a researcher, for example, I cannot 'prove' that people told me the truth when they claimed to be more in love with Jesus than ever before as a result of the renewal, but nor do I have any reason to be skeptical of such self reporting" (Poloma, 2002a).

In her report, Poloma does not want to leave a horizon of sociology as a scientific discipline, she, however, deprives sociology-it should not escape our attention-of the claim to 'objectivity.' At the same time, her report is not-because of her personal conversion-a text which from the start condemns itself to staying outside the academic discourse, but a text fighting for existing in the center of this discourse.

\section{A Change of Horizon and Founding Tales}

When it is time to set off on a trip to 'the new world' and when 'the new world' attracts and encourages to leave the old cognitive horizon and the language typical for it, or when instability and returns appear (just a gentle return of a previous way of thinking and speaking, blended into the habitus of the former community); there is a time of convincing-arguing for and against, by oneself and (even more interestingly) by others.

If the dialectics of horizons is their 'conversation,' sooner or later, a proposal can be put forward to change a horizon by the other side (frequently called 'opposite side') - to 'convert' and 'change to new faith,' for example to the faith in Sigmund Freud's psychoanalysis, Jacques Derrida's deconstructionism, or Charles Taylor's narrativism. Such a proposal attracts to its own horizon-it usually demonstrates its advantage over the horizon that should be left behind, however, it also reveals (which I will consider first) a certain founding tale. Such name is used by Erazm Kuźma (1999, p. 21), who refers to a Polish writer, Bolesław Leśmian as the 'father' of the term. Kuźma states "that at the beginning of every statement there is a founding tale fixing arbitrarily: it is so and so," and quotes Leśmian, who elaborated on this thought in his work entitled Literary Sketches: "The tale is never proven, always beyond the boundary of logic, gilding as if side-effectedly on the margins of experimental life-but it plays a serious role in our thinking: the role of the rainbow bridge that connects us to the 
illogical field of existence, the banks of the mystery, whose face is not similar to a human face" (ibid.). Following this quotation, Kuźma writes, "The theses: the era of the eye is followed by the era of language, fallocentrism is followed by histerocentrism, language creates a thing and not the other way round-these are some founding tales. Or in the rhetoric of Kuhn: this is a proposal for a paradigm shift. Or in the language of Rorty: this is a new metaphor coined to convey a new dictionary, better, or at least differently shaping the world" (ibid.).

"This founding tale, this new metaphor, the act of faith, this new paradigm" (ibid., p. 22) is placed, as Kuźma wants it to be placed, at the beginning of an argument, but it is rarely a beginning understood as incipit, i.e. the first words of a text. It is rather a matter of placing a founding tale at the root or in the background of an argument; often only in a mutely assumed, unutterable horizon of this argument. A founding tale is sometimes told, however only on special occasions. Does a proposal of a horizon change constitute such an occasion? Or maybe such an occasion is constituted by a situation in which a person switches his/ her own horizon to ours, i.e. he/she converts and this conversion is accompanied by a rite of passage (present also in research communities)? As every rite, the rite of passage in a research community can require a reference to a myth of the origin of the community; therefore, a founding tale can be evoked in the rite as a necessary component of a collective anamnesis i.e. recalling and remembering what happened in illo tempore, when-let us say it-a progenitor of a research community, a 'classic' for today's members, founded a new scientific school with his/her concepts and theories. A rite of passage does not have to confirm the conversion i.e. 'initiation' into a new 'scientific faith,' because it may be only a recognition of mandatory 'coming of age' in this faith, as it happens in the case of exams, especially those which are connected with obtaining scientific or professional degrees and examine the knowledge of the fundamentals of this 'faith.' For instance, during such an exam concerning the bases of an 'ethnographic faith,' questions about the 'founding fathers' may be asked and about their views. Some questions can be accompanied by a 'silent expectation' that the 'founding fathers' will be referred to, even during the conversation about the most contemporary views on given topics. Therefore, a founding tale of Polish ethnography and its founding fathers (including Kazimierz Moszyński, Jan Stanisław Bystroń and Józef Obrębski) should always be mentioned when for example a question about an ethnographic group appears (a more contemporary ethnographer dealing with Lemkos-Roman Reinfuss should also be mentioned, but it is not enough to remember only about him). 
For Erazm Kuźma, a founding tale is identical to establishing a 'new metaphor.' However, it is not just any metaphor. This metaphor is a fundamental and, at the same time, arbitrary statement: this is so, transformed into: this is it, so-according to the concept of George Lakoff and Mark Johnson (2003)-reaching a form of ' $X$ is Y.' Such a statement has to 'assume' the whole way of thinking, seeing the world and speaking about it, so it has to be a base, root metaphor-a formative metaphor i.e. a metaphor that lays foundations for the research paradigm. As Nina D. Arutjunova (1990, p. 14) accurately notices, “The key (base) metaphors which formerly attracted mainly the attention of ethnographers and culturologists, examining the images of the world specific for different nations, in the last few decades have been found interesting by specialists in psychology of thinking and methodology of science. A significant contributions to the expansion of these issues have made by the works of M. Johnson and G. Lakoff."

Not only statements 'this is so' and metaphors ' $X$ is $Y$,' but also counterstatements and counter-metaphors: 'this is not so' and ' $X$ is not $Y^{\prime}$ are crucial from a methodological point of view-as components of founding tales. At the level of critical comments and refutation (i.e. rejection and invalidation), some argue that the old metaphor is inadequate, that conversion to the new metaphor requires complete abandonment of the old one, that we are still-it is a wording characteristic for Richard Rorty-'worshipping its corpse' when it is time to overcome the "laziness of spirit" and liberate ourselves-as Erazm Kuźma (1999, p. 25) adds-from the perseverance in the "stale language" and repeating old, uncreative metaphors as "incantations," or from using them-to refer to Tadeusz Różewicz-in constant recycling that grinds emptiness and cliché (ibid., p. 28).

Usually, encouragement to change horizons i.e. to conversion does not end with the presentation of the founding tale. Those who argue that it is worth converting often use 'true-life images.' A good image is expected to reveal, present or animate some general idea by bringing the reality closer, to 'move with the image,' in this case-an image of one's own conversion to a new 'scientific faith.' It concerns especially story-like images. In such situation, it is said that a 'colorful image' clears up the essence of a scientific turning point, makes it possible to understand the transformation, introduces into its crux by presenting the truth of the scientific turning point, especially of the accompanying doubts and mental crossroads, but also sudden inspirations and uplifting hope. Some of such narrative images assure that they contain a description of a 'representative event,' or the whole series of such events-episodes and sequences characteristic of a given scientific community as a whole (I think that Margaret M. Poloma treats her casus in such a way-as something characteristic or 
typical for many Christian sociologists). A story of those events can be a "representative anecdote." According to Kenneth Burke, "Dramatism suggests a procedure to be followed in the development of a given calculus, or terminology. It involves the search for a 'representative anecdote,' to be used as a form in conformity with which the vocabulary is constructed" (Marx, 2004, p. 96; footnote 2). It is worth noticing that the 'construction of vocabulary' means familiarizing the reality through words, including its image into language, which results in, sometimes initial, understanding. However, we should not forget that we owe this understanding also to the narrative character of an anecdote: a 'representative anecdote' is a story, and, as a story, it has a special ability of convincing 'by using an example': by referring to our life experiences and translating (or 'projecting') the experiences of other people known from their tales as well as recognizing general truths and rules (according to which others are living or used to live) on the base of those illustrations i.e. sensing and understanding the world 'from the perspective of the others,' including the scientific perspective. Do illustrations (especially the narrative ones) used in scientific communities discourse in the humanities have to be always real i.e. authentic? Can those not be imaginary (but 'moving') examples-that stimulate mind and become embedded in the heart-like exempla which were used as edifying disquisitions? I am leaving this question without a simple answer, because it deserves a deeper reflection, and an answer which is more complex and balanced at the same time...

\section{References}

Arutjunova, N.D. (1990). Metafora i diskurs (vstupitel'noe slovo). In N.D. Arutjunova \& M.A. Zhurinskaja (Eds.), Teorija metafory (pp. 5-32). Moskva: Progress.

Barbour, I.G. (1974). Myths, Models and Paradigms: A Comparative Study in Science and Religion. New York: Harper \& Raw.

Blackburn, S. (2005). Oxford Dictionary of Philosophy. Oxford - New York: Oxford University Press.

Bronk, A. (2003). Podstawy nauk o religii. Lublin: Towarzystwo Naukowe Katolickiego Uniwersytetu Lubelskiego.

Csordas, T.J. (1994). The Sacred Self: A Cultural Phenomenology of Charismatic Healing. Berkeley - Los Angeles - London: University of California Press.

Dupré, L. (2003). Inny wymiar: Filozofia religii. (S. Lewandowska-Głuszyńska, Trans.). Kraków: Wydawnictwo Znak. 
Dziewulski, G. (2002). Świadectwo chrześcijańskie. In M. Rusecki, K. Kaucha, I. S. Ledwoń, \& J. Mastej (Eds.), Leksykon teologii fundamentalnej (pp. 1189-1191). Lublin - Kraków: Wydawnictwo WAM.

Frank, A.W. (1995). The Wounded Storyteller: Body, Illness, and Ethics. Chicago London: University of Chicago Press.

Hervieu-Léger, D. (2000). Religion as a Chain of Memory. (S. Lee, Trans.). New Brunswick - New Jersey: Rutgers University Press.

Kostkiewiczowa, T. (2000). Przekładalność [entry]. In J. Sławiński (Ed.), Stownikterminów literackich (pp. 447-448). Wrocław: Zakład Narodowy im. Ossolińskich.

Kuhn, T.S. (2012). The Structure of Scientific Revolutions. Chicago - London: University of Chicago Press.

Kuźma, E. (1999). Język-stwórca rzeczy. In S. Wysłouch \& B. Kaniewska (Eds.), Człowiek i rzecz: O problemach reifikacji w literaturze, filozofii $i$ sztuce. Poznań: Instytut Filologii Polskiej.

Lakoff, G., \& Johnson, M. (2003). Metaphors We Live By. London: University of Chicago Press.

Lawson, M.P. (1999). The Holy Spirit as Conscience Collective. Sociology of Religion, 4 (60), 341-361.

Lonergan, B.J.F. (2003). Method in Theology. Toronto: Toronto University Press.

Marx, L. (2004). Pastoralizm w Ameryce. In A. Preis-Smith (Ed.), Kultura, tekst, ideologia: Dyskursy wspótczesnej amerykanistyki (pp. 95-132). (M. Paryż, Trans.). Kraków: Towarzystwo Autorów i Wydawców Prac Naukowych Universitas.

Murray, K.D. (1995). Narratology. In J.A. Smith, R. Harré, \& L. Van Langenhove (Eds.), Rethinking Psychology (pp. 179-195). London - Thousand Oaks: Sage. Online version of the text: Narrative Partitioning: The Ins and Outs of Identity Construction, http://home.mira.net/ kmurray/psych/in\&out.html [last accessed: June 21, 2003].

Owczarek, P. (2006). Karol Wojtyła-Jan Paweł II: Podhalańska opowieść o świętym: Od historii do mitu-studium antropologiczne. Kraków: Wydawnictwo Avalon.

Poloma, M.M. (2002a). Fruits of the Father's Blessing: A Sociological Report, http:// www3.uakron.edu/sociology/FRUITS.pdf [last accessed: June 7, 2005].

Paloma, M.M. (2002b). "Toronto Blessing" [entry]. In S.M. Burgess \& E.M. van der Maas (Eds.), The New International Dictionary of Pentecostal and Charismatic Movements. Grand Rapids - Michigan: Zondervan. 
Paloma, M.M. (2001). Pilgrims' Progress: An Exercise in Reflexive Sociology, http:// hirr.hartsem.edu/research/pentecostalism_polomaart9.html [last accessed: October 10, 2013].

Paloma, M.M. (1997). The "Toronto Blessing": Charisma, Institutionalization, and Revival. Journal for the Scientific Study of Religion, 2 (36), 257-271.

Ricoeur, P. (1988). Time and Narrative, Vol. 3. (K. McLaughlin \& D. Pellauer, Trans.). Chicago: University of Chicago Press.

Ricoeur, P. (1980). The Hermeneutics of Testimony. In L.S. Mudge (Ed.), Essays on Biblical Interpretation (pp. 119-154). Philadelphia: Fortress Press.

Trigg, R. (1973). Reason and Commitment. London - New York: Cambridge University Press.

Uehara, E.E., Farris, M., Morelli, P.T., \& Ishisaka, A. (2001). "Eloquent Chaos" in the Oral Discourse of Killing Fields Survivors: An Exploration of Atrocity and Narrativization. Culture, Medicine and Psychiatry, 25, 29-61.

w.a. (2009). Conversionism [entry]. In J. Scott \& G. Marshall (Eds.), A Dictionary of Sociology. Oxford - New York: Oxford University Press.Wejland, A.P. (2010). Dyskurs i tożsamość: Opowieści we wspólnocie naukowej. In I. Taranowicz \& Z. Kurcz (Eds.), Okolice socjologicznej tożsamości: Księga poświęcona pamięci Wojciecha Sitka (pp. 155-182). Wrocław: Wydawnictwo Uniwersytetu Wrocławskiego.

Wejland, A.P. (2004). Wspólnota świadectwa: Charyzmatyczne opowieści o uzdrowieniu. In G.E. Karpińska (Ed.), Codzienne i niecodzienne: O wspólnotowości w realiach dzisiejszej Łodzi (pp. 29-77). Łódź: Polskie Towarzystwo Ludoznawcze.

Wejland, A.P. (2003). Parrhesia-piękne i mądre słowo. Szum z Nieba, 4, 26-27.

Wierzbicka, A. (2001). What Did Jesus Mean? Explaining the Sermon on the Mount and the Parables in Simple and Universal Human Concepts. New York: Oxford University Press.

Wolicka, E. (2003). Odkrywanie tożsamości "Ja"-hermeneutyka Paula Ricoeura "w drodze" ku fenomenologii osoby. In A. Grzegorczyk, M. Loba, \& R. Koschany (Eds.), Horyzonty interpretacji: Wokót myśli Paula Ricoeura (pp. 99-111). Poznań: Fundacja Humaniora. 